2013s-17

\title{
Patterns of Specialization and (Un)conditional Convergence: The Cases of Brazil, China and India
}

\author{
Marine Hadengue, Thierry Warin
}

Série Scientifique
Scientific Series

\author{
Montréal \\ Juin 2013
}

(C) 2013 Marine Hadengue, Thierry Warin. Tous droits réservés. All rights reserved. Reproduction partielle permise avec citation du document source, incluant la notice $($ ).

Short sections may be quoted without explicit permission, if full credit, including (C) notice, is given to the source.
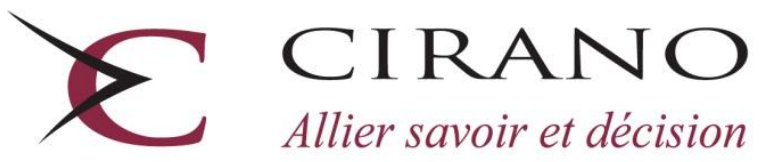

Allier savoir et décision

Centre interuniversitaire de recherche en analyse des organisations 


\section{CIRANO}

Le CIRANO est un organisme sans but lucratif constitué en vertu de la Loi des compagnies du Québec. Le financement de son infrastructure et de ses activités de recherche provient des cotisations de ses organisations-membres, d'une subvention d'infrastructure du Ministère du Développement économique et régional et de la Recherche, de même que des subventions et mandats obtenus par ses équipes de recherche.

CIRANO is a private non-profit organization incorporated under the Québec Companies Act. Its infrastructure and research activities are funded through fees paid by member organizations, an infrastructure grant from the Ministère du Développement économique et régional et de la Recherche, and grants and research mandates obtained by its research teams.

\section{Les partenaires du CIRANO}

\section{Partenaire majeur}

Ministère de l'Enseignement supérieur, de la Recherche, de la Science et de la Technologie

Partenaires corporatifs

Autorité des marchés financiers

Banque de développement du Canada

Banque du Canada

Banque Laurentienne du Canada

Banque Nationale du Canada

Banque Scotia

Bell Canada

BMO Groupe financier

Caisse de dépôt et placement du Québec

Fédération des caisses Desjardins du Québec

Financière Sun Life, Québec

Gaz Métro

Hydro-Québec

Industrie Canada

Investissements PSP

Ministère des Finances et de l'Économie

Power Corporation du Canada

Rio Tinto Alcan

State Street Global Advisors

Transat A.T.

Ville de Montréal

\section{Partenaires universitaires}

École Polytechnique de Montréal

École de technologie supérieure (ÉTS)

HEC Montréal

Institut national de la recherche scientifique (INRS)

McGill University

Université Concordia

Université de Montréal

Université de Sherbrooke

Université du Québec

Université du Québec à Montréal

Université Laval

Le CIRANO collabore avec de nombreux centres et chaires de recherche universitaires dont on peut consulter la liste sur son site web.

Les cahiers de la série scientifique (CS) visent à rendre accessibles des résultats de recherche effectuée au CIRANO afin de susciter échanges et commentaires. Ces cahiers sont écrits dans le style des publications scientifiques. Les idées et les opinions émises sont sous l'unique responsabilité des auteurs et ne représentent pas nécessairement les positions du CIRANO ou de ses partenaires.

This paper presents research carried out at CIRANO and aims at encouraging discussion and comment. The observations and viewpoints expressed are the sole responsibility of the authors. They do not necessarily represent positions of CIRANO or its partners. 


\title{
Patterns of Specialization and (Un)conditional Convergence: The Cases of Brazil, China and India*
}

\author{
Marine Hadengue ${ }^{\dagger}$, Thierry Warin
}

\begin{abstract}
Résumé / Abstract
The purpose of this paper is to highlight a version of the Balassa-Samuelson effect for emerging countries with a new dataset. More than the catching-up effect, we will measure the convergence for three emerging countries: Brazil/China/India. We will compare the convergence between these countries and the productivity frontier represented by the U.S. over the past 10 years. A first contribution is that as the distance between the level of labor productivity in Brazil (China, India) and the United States decreases, the growth rate of labor productivity within the country decreases. In other words, the higher the level of productivity in an industry, the lower its growth rate, showing a convergence to the productivity frontier. A second contribution is that there is unconditional convergence as measured at the industry level.
\end{abstract}

Mots clés/keywords : economic convergence, endogenous growth, Brazil, China, India, labor productivity.

Codes JEL: O40, O41, O43, O47, O53

\footnotetext{
* We would like to thank CIRANO and the GMT Lab (Polytechnique Montréal) for their support. Our thanks go to the participants of the IAES and IT\&FA conferences (Montreal, 2013) and the IFBAE conference (Tours, 2013); the usual caveats apply.

${ }^{\dagger}$ PhD Student, Department of Mathematics and Industrial Engineering, Polytechnique Montréal (Canada).

$\$$ Corresponding author: thierry.warin@ polymtl.ca. Associate Professor, Department of International Business, HEC Montréal (Canada), Vice-President at CIRANO (Canada).
} 


\section{Introduction}

Emerging and developing countries represent roughly half of the world GDP and are the main contributors to the bulk of world growth (Builter and Rahbari 2011). This paper aims at revisiting the models of growth and more specifically the convergence of growth between emerging and developed countries. In the midst of a globalization of the value chains, measuring the world based on data, whose geographical scope is political, does not help capture the new world economic reality. This is why we need to work on the right data to collect as well as use the right methodology to understand these data. The present paper does not pretend to provide all the answers, but our aim is to be part of this conversation.

The goal of this paper is twofold: (1) based on a large dataset built around industrial sectors in each country (China, India, Brazil, U.S.), we study the notion of convergence based on a pooled approach at the industry level first, and (2) we study the convergence at some industry level. Clearly, this work does not intend to be exhaustive, indeed the limitations we have with the data prevent us from being too definitive. Nevertheless, we hope that the approach we design here lays out the path for further interesting research.

The current study focuses on Brazil, China and India. In 2010, populations of these three countries represented more than $45 \%$ of the world population. ${ }^{2}$ According to Buiter and Rahbari (2011), China will even become the largest economy in the world by 2030 and will itself be second to India by 2050. The following graph (Figure 1) gives us some interesting information about the economic evolution of Brazil, China and India in the past two decades.

Figure 1- GDP per capita, annual growth in \% (constant 2005 international \$)

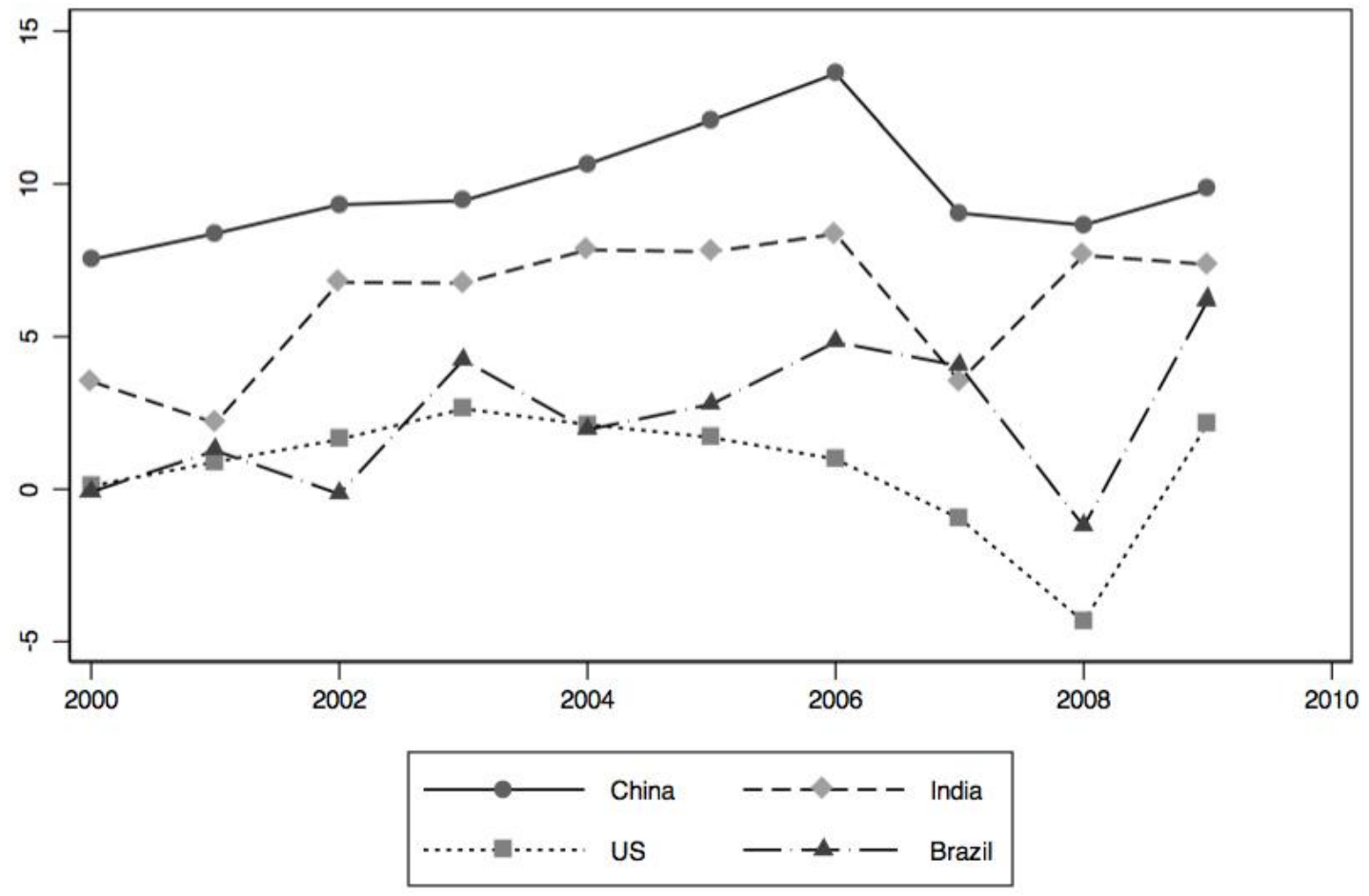

Source: Author's calculations using World Bank 2011 data

Before the crisis, the high annual growth of Brazil, China and India compared to the United States (which is even negative between 2007 and 2009) is already an indicator of convergence between these emerging

${ }^{2}$ According to author's calculations from World Bank data. 
economies and the U.S. economy. Brazil, China and India are very interesting case studies in this regard. But instead of looking at this convergence at the aggregate level, our study relies on a more micro-level approach. Indeed, industrial firms play an important role in emergent countries. Exports have drastically increased over the years to levels of $24 \%, 30 \%$ and $25 \%$ of the GDP in Brazil, China and India in 2011 (compared, for example, to 12\% in the U.S.) (The World Bank 2011). And what is more interesting than overall convergence is to look at which industrial sectors are actually converging.

As the manufacturing sector accounts for respectively $60 \%, 93 \%$ and $64 \%$ of Brazilian, Chinese and Indian exports in 2010 (The World Bank 2011), we should look more closely at the evolution of this sector. Despite a slowdown, the number of manufacturing establishments in China has generally doubled in less than 10 years. Brazil has also experienced an important increase of every industry in general. India's manufacturing sector has stayed stable or has increased too. In comparison, we observe that for the U.S., almost every sector has experienced a slowdown (except for beverages, non-metallic mineral products and structure metal products), although the global industry sector has slightly increased. Unfortunately, we do not have the data from 2006 onwards for the U.S. However, we can assume that the economic crisis has not helped and that the number of establishments has continued to fall at least until 2009. This big picture shows that the advantage goes to Brazil, China and India.

Figure 2- Normalized evolution of the number of establishments in the manufacturing sector for major industry types in Brazil

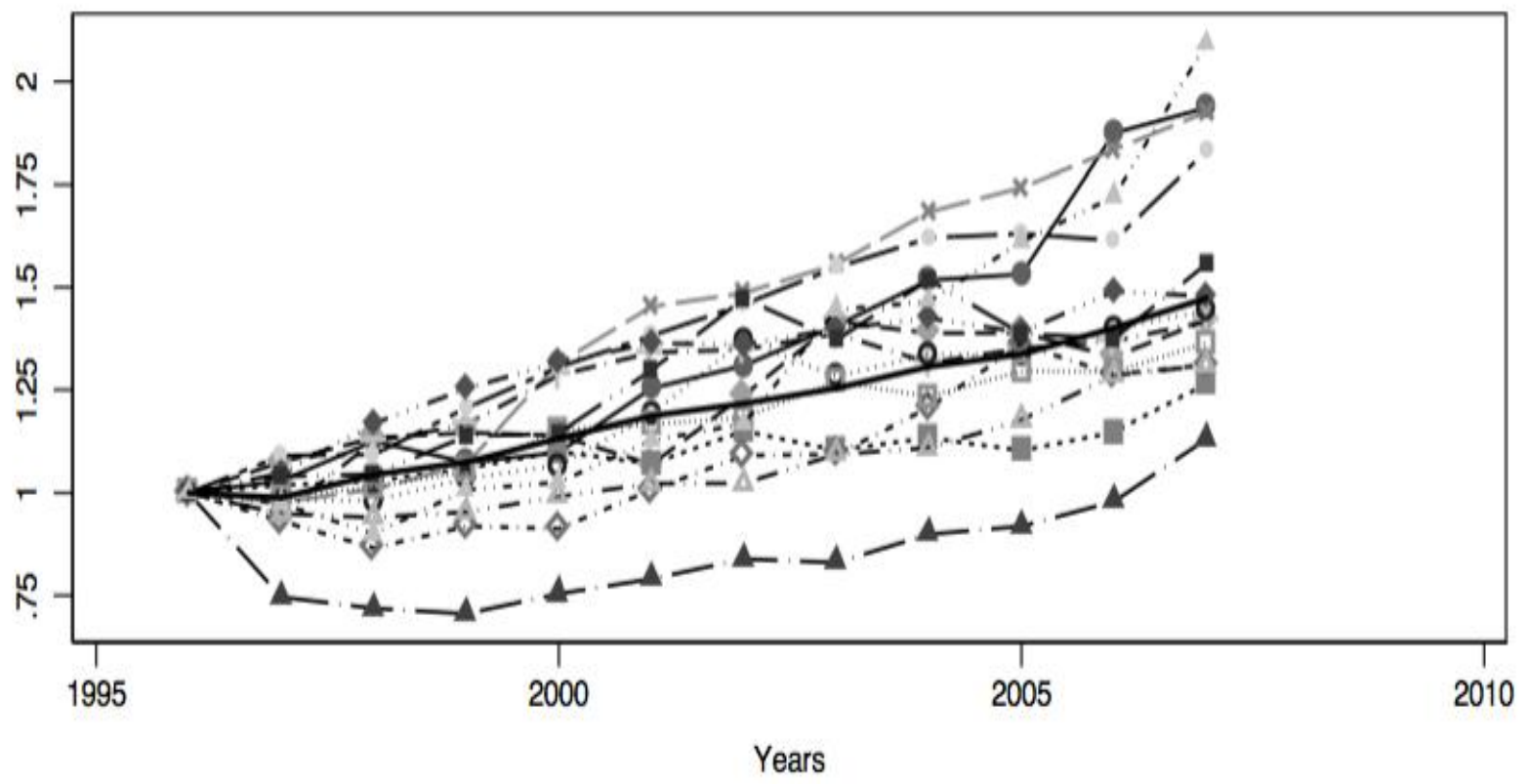

\begin{tabular}{|c|c|c|c|}
\hline$\rightarrow-$ & Processed meat, fish, fruit, vegetables, fats & $-\triangleleft-$ & Grain mill products \\
\hline$\cdots=\cdots$ & Beverages & $\rightarrow-$ & Spinning, weaving and finishing of textiles \\
\hline$-x$ & Footwear & -+- & Products of wood, cork, straw, etc. \\
\hline 0 & Paper and paper products & $\because \diamond \cdots$ & Basic chemicals \\
\hline ….............. & Special chemicals & $-\Delta-\cdot$ & Rubber products \\
\hline$\cdots \cdots$ & Plastic products & $-\bullet-$ & Non-metallic mineral products \\
\hline$\rightarrow-$ & General purpose machinery & $\underline{-1}$ & $\begin{array}{l}\text { Special purpose machinery } \\
\text { TOTAL ( } 55 \text { industries) }\end{array}$ \\
\hline
\end{tabular}

Source: UNIDO database, 2011 
Figure 3- Normalized evolution of the number of establishments in the manufacturing sector for major industry types in China

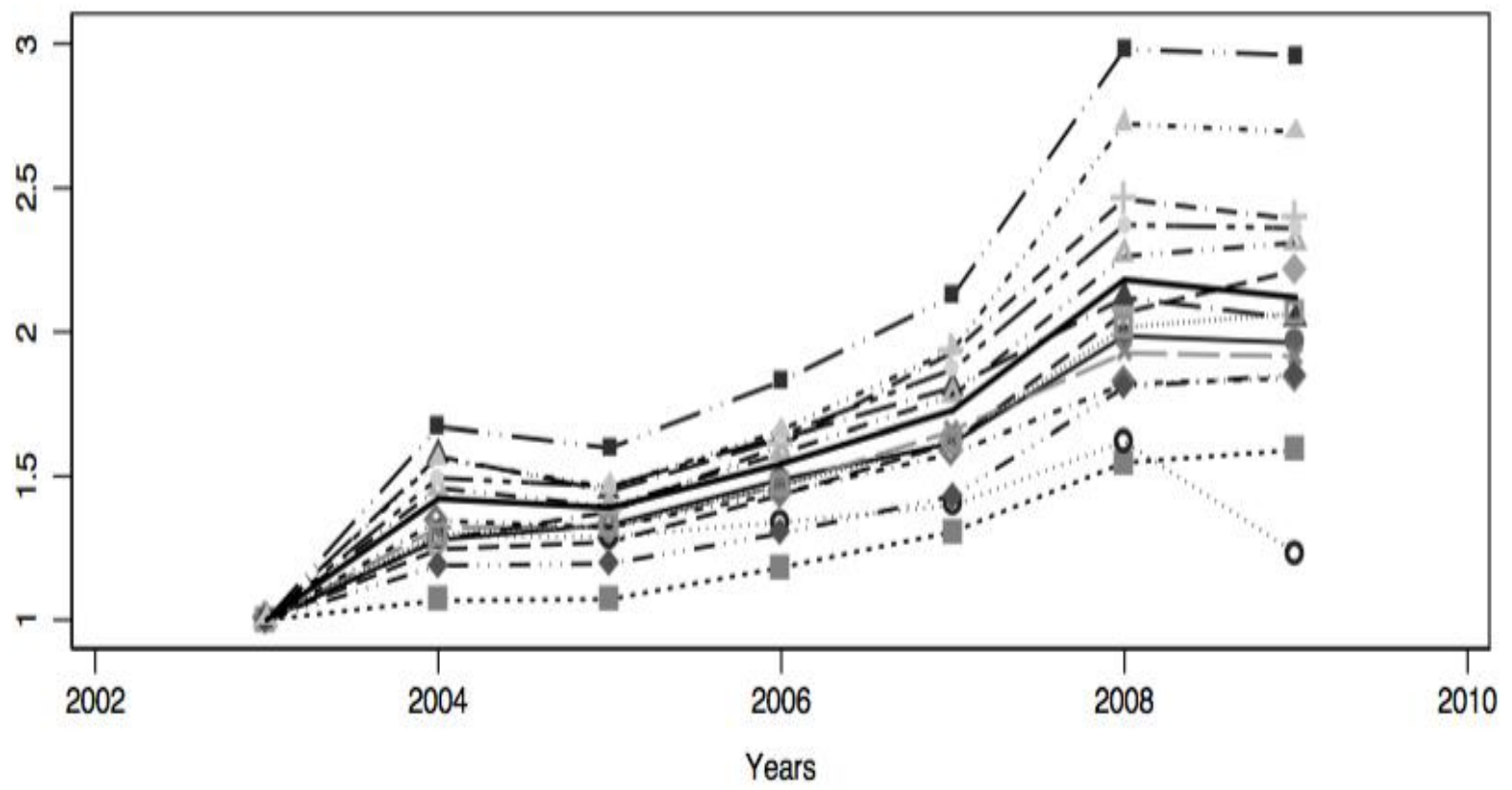

\begin{tabular}{|c|c|c|c|}
\hline$\rightarrow-$ & Processed meat, fish, fruit, vegetables, fats & $-\Delta-$ & Grain mill products \\
\hline$\cdots=\cdots$ & Beverages & $\rightarrow-$ & Spinning, weaving and finishing of textiles \\
\hline$\longrightarrow$ & Footwear & -+- & Products of wood, cork, straw, etc. \\
\hline 0 & Paper and paper products & $-\infty$ & Basic chemicals \\
\hline$(\ldots+\cdots \cdots \cdots$ & Special chemicals & $-\Delta-$ & Rubber products \\
\hline$-\cdots$ & Plastic products & $-\bullet-$ & Non-metallic mineral products \\
\hline$\rightarrow-$ & General purpose machinery & 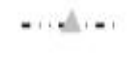 & Special purpose machinery \\
\hline
\end{tabular}

Source: UNIDO database, 2011 
Figure 4- Normalized evolution of the number of establishments in the manufacturing sector for major industry types in India

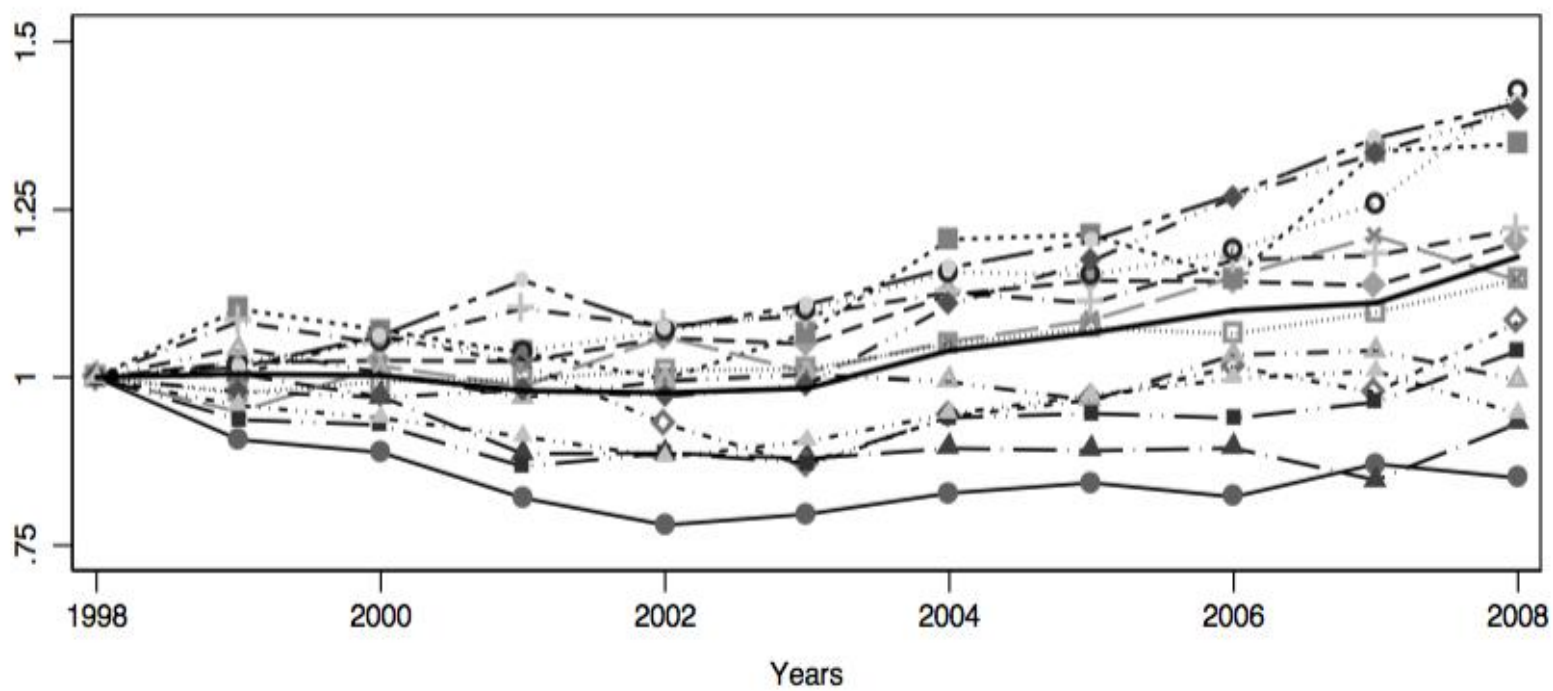

\begin{tabular}{|c|c|c|c|}
\hline-0 & Processed meat, fish, fruit, vegetables, fats & $-\diamond-$ & Grain mill products \\
\hline$\cdots=\cdots$ & Beverages & $\rightarrow-$ & Spinning, weaving and finishing of textiles \\
\hline$\longrightarrow x$ & Footwear & -+- & Products of wood, cork, straw, etc. \\
\hline$\ldots$ & Paper and paper products & $--\diamond-$ & Basic chemicals \\
\hline 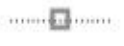 & Special chemicals & $-\Delta-\cdots$ & Rubber products \\
\hline - $\cdots$ & Plastic products & $-\bullet-$ & Non-metallic mineral products \\
\hline$\longrightarrow$ & General purpose machinery & $\underline{-\cdots+1}$ & $\begin{array}{l}\text { Special purpose machinery } \\
\text { TOTAL (139 industries) }\end{array}$ \\
\hline
\end{tabular}

Source: UNIDO database, 2011 
Figure 5- Normalized evolution of the number of establishments in the manufacturing sector for major industry types in the U.S.

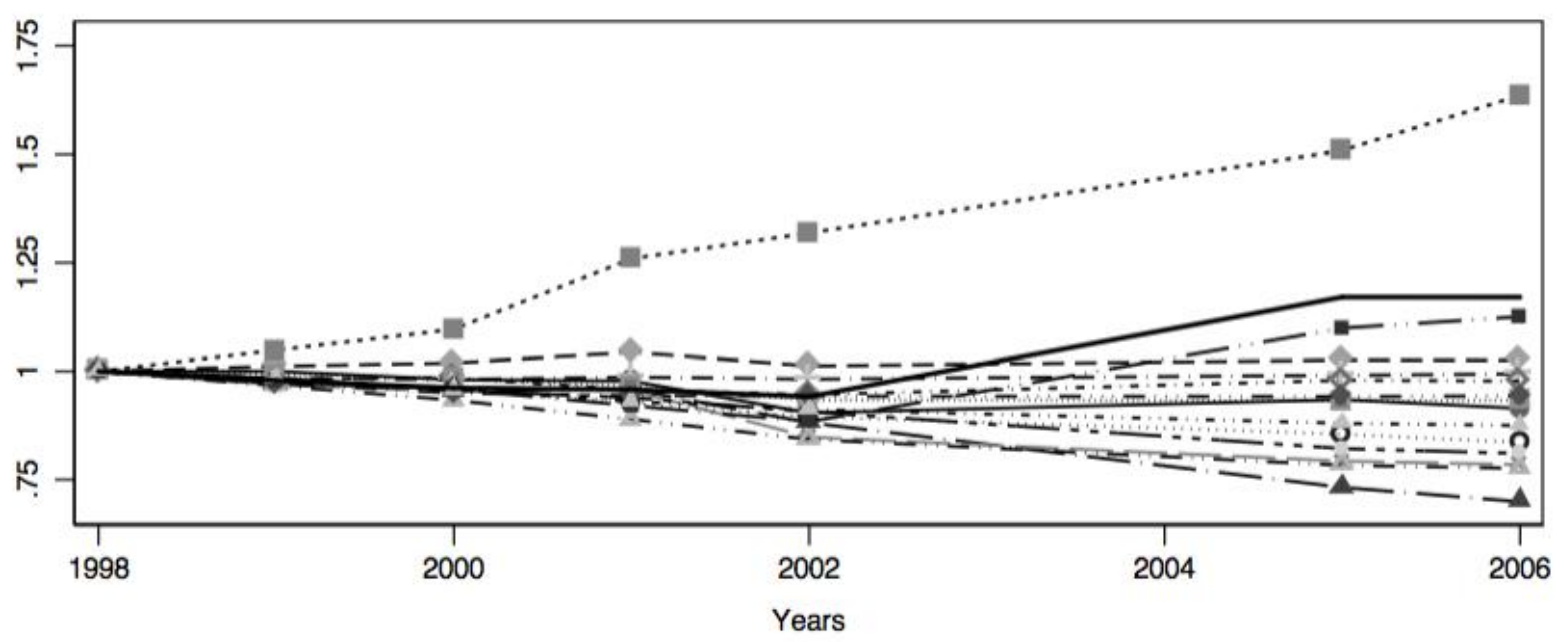

\begin{tabular}{|c|c|c|c|}
\hline$\longrightarrow$ & Processed meat, fish, fruit, vegetables, fats & $-\Delta-$ & Grain mill products \\
\hline$\cdots[\cdots$ & Beverages & $\longrightarrow$ - & Spinning, weaving and finishing of textiles \\
\hline$\longrightarrow$ & Footwear & -+- & Products of wood, cork, straw, etc. \\
\hline$\ldots$ & Paper and paper products & $-\infty \cdots$ & Basic chemicals \\
\hline ……무…....... & Special chemicals & $-\Delta-\cdots$ & Rubber products \\
\hline$\longrightarrow \cdots$ & Plastic products & -1 & Non-metallic mineral products \\
\hline$\longrightarrow-$ & General purpose machinery & $-\cdots$ - $^{-}$ & Special purpose machinery \\
\hline & & & TOTAL (151 industries) \\
\hline
\end{tabular}

Source: UNIDO database, 2011

In this regard, it might be very interesting to look at the evolution of labor productivity in these countries. Indeed, considering their active population and the recent fast-pace development of the manufacturing sector, we assume that these emerging countries may start having important absolute comparative advantages. Moreover, it is important to emphasize that the size of their own population provides them with a huge domestic market. Independently of any other control variable (political measures, economic measures, etc.), we could eventually find unconditional convergence for these three countries.

It is in this context that this paper tests whether the convergence hypothesis can be validated for these three countries. We will try to identify labor productivity convergence in the manufacturing sector between each of these countries and the United States. This type of convergence is different from the wellknown $\beta$-convergence, which checks convergence of an entire sample of countries or regions. It is also different from the $\sigma$-convergence, which is particularly interested in the shape of the variance in growth rate. For the sake of a name and clarity, we modestly decided to name it: $\delta$-convergence. The choice of the U.S. as the country of reference is not a coincidence, as it remains up to four times the more productive country at the manufacturing level before Germany or France in the main sectors. ${ }^{3}$ In what follows, we present a brief literature review on the types of convergence. Then the data and models are described in section 3. In section 4, these models are tested (for all industries and by industry) for each country and the results are presented.

${ }^{3}$ According to author's calculations and using UNIDO data : the productivity is obtained by dividing each sector's added value by the number of employees at the time. 


\section{Literature review}

This study is inspired by Rodrik (2012) who finds unconditional convergence measured through labor productivity in manufacturing (detailed by type of industry according to the Industrial Statistics Database at the four-digit level) over 10 years for a total of 40 countries. The results are interesting insofar as they oppose the conclusions of recent works on convergence. Indeed, if unconditional convergence was verified for all sectors, then developing countries should have almost caught up with developed countries in terms of labor productivity. Moreover, according to the factor price equalization theorem, ratios of wages over cost of capital in developing countries should evolve towards ratios of wages over cost of capital in developed countries. If two countries meet the conditions of the $\mathrm{H}-\mathrm{O}$ model $^{4}$ and their inputs do not differ "too much", then the free exchange of goods leads to an equalization of factor prices, even if "there is no mobility of these factors" (Mundell 1957). In other words, since international trade leads to the equalization of ratios of final goods prices between countries, then the factors prices (including wages) should also be adjusted. However, some new theories of international trade came to change the assumptions of the old traditional models. The configuration of international trade, the diffusion of ideas, the elimination of duplication in research were also studied in the literature (Aghion and Howitt 1992; Grossman and Helpman 1990; L. A. Rivera-Batiz and Romer 1991; Segerstrom, Anant, and Dinopoulos 1990). These phenomena have an impact on the production factors. Moreover, the factor price equalization theorem has been questioned in the literature (Leamer and Levinsohn 1994; Repetto and Ventura 1997; L. A. Rivera-Batiz and Oliva 2003; Trefler 1995) and unconditional convergence of labor productivity does not automatically imply a convergence of the global economy, which has been widely validated empirically in the literature (Rodrik 2012).

This paper is part of this literature on economic growth and most particularly on labor productivity convergence. An important part of the economic growth literature is dedicated to the convergence concept. Convergence is defined in two ways: (1) when countries (or regions) converge to a steady state, which is the same for all, (2) but it can also be if countries (or regions) are considered to converge each to their own steady state (Barro and Sala-i-Martin 2004). Generally, convergence is measured through per capita income (GDP per capita) or labor productivity. It can be conditional or unconditional.

In the case of unconditional $\boldsymbol{\beta}$-convergence, there is a correlation between growth and the initial value, and this, without adding control variables in the following regression:

$$
\hat{\mathrm{y}}_{\mathrm{T}}=\alpha_{0}+\beta \cdot \mathrm{y}_{0}+\varepsilon
$$

$\hat{\mathrm{y}}_{\mathrm{T}}$ is the annual growth rate and the initial value is $\mathrm{y}_{0}$ (initial income or labor productivity). The coefficient of interest $\beta$ has a negative value. The first work on the subject was done by Baumol (1986) and covers a sample of 16 OECD countries. Pritchett (1997), using a larger sample of countries, shows that while rapid gains in productivity are possible, this is not what is observed empirically. Since the industrial revolution, developing countries have had an experience of divergence rather than convergence with rich countries (Pritchett 1997). In their theoretical study of 2001, Baldwin, Martin, and Ottaviano (2001) confirm Pritchett's result although expecting a return to convergence explained by the decreasing transaction costs. Recent studies from Sala-i-Martin (2006), Rodrik (2012) and Barro (2012) confirm the intuition (discussed below).

\footnotetext{
${ }^{4}$ For more details on the hypothesis, see (Mundell 1957; Ohlin 1933; Rybczynski 1955; Samuelson 1948; Samuelson 1949).
} 
In the case of conditional $\boldsymbol{\beta}$-convergence:

$$
\hat{y}_{T}=\alpha_{0}+\beta \cdot y_{0}+\gamma^{\prime} \cdot \Phi+\varepsilon
$$

with $\Phi$ a vector of control variables such as, for example, human capital, savings rate, population growth, technology or the rate of capital depreciation. All this literature is, of course, linked with the neoclassical growth model from Solow (1956), which implies that countries with similar production functions at a given time should see their incomes converge to their steady state through time. In short, it is conditional convergence (G. Mankiw, Phelps, and Romer 1995). The growth rate is regressed on the initial income with other control variables determining the steady state (variables in the vector $\Phi$ of equation 2 ). In the case of $\boldsymbol{\sigma}$-convergence, it emerges in response to criticisms (Friedman 1992; Quah 1993) which consider that a negative value of the coefficient is not sufficient to prove convergence and that an assessment of the standard deviation of the distribution of the dependent variable (growth rate of per capita income or productivity) in cross section is required to validate the hypothesis (Islam 2003). Also, according to Islam (2003), the literature about $\sigma$-convergence is divided in two branches: (1) one that maintains and tries to explain the relationship between $\sigma$ and $\beta$-convergences and (2) one that emphasizes the limitations of the latter. Indeed, $\sigma$-convergence has the advantage of indicating whether the distribution of income across economies is becoming more equitable (Friedman 1992; Quah 1993).

The debate is far from being over and researchers continue to be interested in the $\beta$-convergence since it is still necessary, although not sufficient, for the $\sigma$-convergence (Islam 2003; Andrew Young, Higgins, and Levy 2005). To our knowledge, there is no work evaluating the $\delta$-convergence. Indeed, rather than focusing on the convergence of income or productivity of an entire sample of countries or regions compared to a steady state (shared or not), the $\delta$-convergence analyzes convergence between the level of labor productivity of the manufacturing industries of a country and the productivity frontier of that industry at time $t$ in the world. In the case of $\delta$-convergence, the equilibrium state is associated with the productivity frontier and other variables specific to the national growth model (savings rate, growth of population, technology or capital depreciation rate, etc.) are not appropriate.

In 1991, Barro studied the $\beta$-convergence of income in 98 countries between 1960 and 1985 . He found that the latter is conditional on the initial level of human capital (positive correlation) and government expenditures relative to GDP (negative correlation) (Barro 1991). Mankiw, Romer, and Weil (1992) studied $\beta$-convergence in income between 1960 and 1985 on three different samples of countries (those with a developed oil industry, those for whom data were unreliable and, finally, the OECD countries) and found unconditional convergence for the OECD countries and conditional convergence for the two other groups. Barro and Sala-i-Martin (1992) focused on 48 states in the U.S. between 1880 and 1988 and found unconditional $\beta$-convergence. More recently, Dawson and Sen (2007) showed an unconditional $\beta$ convergence in income for a sample of 29 countries (selected according to availability of data provided by Maddison) between 1900 and 2001. In response to the work of Barro and Sala-i-Martin (1992), Young, Levy, and Higgins (2005) reaffirmed the $\beta$-convergence and studied the $\sigma$-convergence across U.S. states. They found a significant $\sigma$-divergence in most cases. In the same vein, Wang (2004) found a discrepancy in income across Chinese provinces between 1991 and 1999, thus questioning the initial results of Choi and Li (2001) who found a conditional $\beta$-convergence between 1978 and 1994. Kaitila, Alho, and Nikula (2007) found unconditional $\beta$-convergence of 21 emerging economies of Central Europe and Eastern Europe.

In 2006, Sala-i-Martin published a new paper on convergence emphasizing some important problems in the previous convergence studies. He explained the lack of consensus of these works by the use of countries as unit of analysis without taking into account population weights (Sala-i-Martin 2006). Adding this factor, he concluded that incomes of the poors tend to increase ( $\beta$-convergence) while inequalities seem to decrease ( $\sigma$-convergence) during the last century.

Very recently, Barro (2012) found conditional convergence of incomes around $2 \%$ for a sample of 80 countries (including developed, developing and emerging countries) between 1960 and 2009. He 
concentrated on the issue of estimation bias by including fixed effects in the regressions. He also confirmed $\sigma$-convergence since the late 1970 s when China and India were included in the tests (Barro 2012). Finally in 2012, Rodrik used data from the Penn World Tables Data compiled by Maddison and found $\beta$ convergence in income for a very large set of countries between 1990 and 2007 periods by regressing 10 years.

Other authors are more focused on the convergence of productivity including labor productivity. Bernard and Jones (1996) examined the unconditional $\beta$-convergence based on productivity for 14 OECD countries between 1970 and 1987. Their main result was a lack of convergence in the manufacturing sector as opposed to unconditional convergence in services. Other authors, such as Carree, Klomp, and Thurik (2000) working on 18 OECD countries between 1972 and 1992, found that convergence varies greatly by industry. They explained this phenomenon by the existence of substantial differences in knowledge and capital. However, Landesmann and Stehrer (2000) found an unconditional $\beta$-convergence in a sample of 33 countries between 1963 and 1997 for the manufacturing sector. They also showed that it seemed faster for medium and high technologies. Castellacci, Los, and Vries (2010) tried to see whether Bernard's and Jones' 1996 conclusions were valid for a larger set of countries. Their sample included 49 countries between 1970 and 2004 for six major industrial sectors. Overall, they confirmed Bernard's and Jones' results only for a small group of countries. Finally, in a recent study, Rodrik (2012) found an unconditional $\beta$-convergence in labor productivity at a highly disaggregated level (more than a hundred manufacturing industry categories) for a set of 72 countries between 1990 and 2007. Hwang (2007) showed that poor countries actually converge towards rich countries unconditionally for all manufactured goods they produce and export. Indeed, Hwang showed that there was a large force of "vertical" convergence: the countries furthest from the technological frontier were those who showed the greatest unconditional economic growth (Hwang 2007). Levchenko and Zhang (2011) assessed the trend in productivity in 19 manufacturing sectors from 1960 to 2000 and showed that there was some convergence across countries: the areas furthest from the technological frontier were those which saw their productivity grow the fastest (Levchenko and Zhang 2011). At the regional level, Jefferson, Rawski, and Zhang (2008) studied $\beta$-convergence among Chinese provinces based on productivity (of labor, capital and multifactor) at the industry level between 1998 and 2005. They found unconditional convergence. Similarly, Marti, Puertas and Fernandez (2011) studied the $\beta$ and $\sigma$-convergences in labor productivity of industrial sectors in the Chinese provinces and found that they were weak. For India, works on convergence were done including the $\sigma$ and $\beta$-convergences of regional growth in agriculture between 1971 and 2007 (Somasekharan, Prasad, and Roy 2011) and the growth of services (services per capita) between 1980 and 2006 (Shingal 2010). The results are respectively a divergence in agriculture and convergence in services. Several econometric issues were also raised in the literature of convergence with a panel-based approach. From a methodological perspective, Islam (2003) concluded that the inclusion of least squares with dummies (LSDV), the minimum distance estimator of Chamberlain (MD) and GMM estimators are among the most reasonable estimators for such models, unless the time frame was not long enough.

\section{Model}

The data used in this paper are from the United Nations Industrial Development Organization (INDSTAT4 ISIC Rev. 3). For non-OECD members, they were collected from national statistical offices of UNIDO (2012). The database provides the value added (in current U.S. dollars) and the number of employees for 151 manufacturing industries in 127 countries between 1990 and 2008 for the most part. In this paper, we use the data for Brazil, China, India and the United States. The data are available respectively between 1997 and 2007, 2003 and 2007, 1998 and 2007, 1997 and 2007. The data cover respectively 55, 135 and 139 out of the 151 industries for Brazil, China and India. Annual labor productivity is calculated by dividing the value added by the number of employees for each industry and each year. To measure this productivity in real terms, we deflate values by using the consumer price index. Different models are used in the literature to assess the convergence of labor productivity. Some authors regress the growth rate of 
labor productivity on the initial labor productivity, others regress the growth rate of labor productivity or the growth rate of the difference in labor productivity between a country and the leading country - on the gap between labor productivity and the leading country's labor productivity.

In our case, data for the labor productivity frontier are the United States'. Indeed, the U.S. remains the most productive in manufacturing according to UNIDO. We will regress the growth rate (biannual) of labor productivity on the ratio of the distance between the labor productivity of industry $i$ at time $t$ and the data in the same industry $i$ at time $t$ in the U.S. The $\delta$-convergence model is specified as follows:

$$
\hat{\mathrm{y}}_{i t}=\beta_{0}+\beta_{1} \cdot \operatorname{RATIO}_{i t}+\mathcal{E}_{i t}
$$

$\hat{y}_{i t}$ is the absolute growth of labor productivity between time $t$ and time $t_{+2}$ and $R A T I O_{i t}$ the distance to the labor productivity frontier for industry $i$ at time $t$.

$$
\begin{aligned}
& \hat{\mathrm{y}}_{\mathrm{it}}=\frac{v_{\mathrm{it}+2}}{v_{i t}} \quad \text { with } \quad v_{i t}=\frac{\text { Added Value }_{i t}}{\text { Number of Employees }} \\
& \text { RATIO }_{i t}=\frac{y_{i t}}{y_{i t}^{U S}}
\end{aligned}
$$

This functional form can be tested to approximate the trend:

$$
\log \left(\hat{\mathrm{y}}_{\mathrm{it}}\right)=\beta_{0}+\beta_{1} \cdot \log \left(\text { RATIO }_{i t}\right)+\varepsilon_{i t}
$$

To check the convergence hypothesis, $\beta_{t}$ should be significant and negative: the growth rate of labor productivity decreases as the distance to the productivity frontier decreases (and thus increases the variable RATIO).

The logarithmic form implies that although there is a positive correlation between the growth rate and a long distance to the productivity frontier, the magnitude of this relationship diminishes as the frontier expands (Equation 4).

Regarding the estimator, the ordinary least squares (OLS) could not be optimal for evaluating this type of data. Indeed, it seems reasonable to assume that there is a positive correlation between distance and the error term, which includes unobserved variables specific to each industry $(C \imath)$. These variables might be positively correlated with the regressor, which automatically induces a positive bias on $\beta_{\text {r. }}$ Since the expected sign of $\beta_{1}$ is negative, then the value estimated by OLS will tend to be less negative than it could be, which will minimize the estimated convergence. Formerly:

$$
E\left(\varepsilon_{i t} \mid R_{A T I O}{ }_{i t}, C_{i}\right)=0
$$

Hence:

$$
\hat{\mathrm{y}}_{\mathrm{it}}=\beta_{0}+\beta_{1} \cdot \text { RATIO }_{\mathrm{it}}+C_{i}+V_{i t}
$$

with:

$$
\operatorname{Corr}\left(\operatorname{RATIO}_{i t}, \mathcal{E}_{i t}\right) \neq 0
$$

A Hausman test was performed showing that a fixed effect model is superior to a random effect model, which is consistent with the literature (Islam 2003; G. Mankiw, Phelps, and Romer 1995). Therefore, we will use the fixed effect method (LSDV).

To further check for robustness, we used the Beck-Katz, Kmenta-Parks, and GMM estimation techniques. Indeed, the presence of serial correlation and panel heteroscedasticity were of key concern in our estimation of this model. If there is autocorrelation, the option would be fourfold: (1) a dynamic panel 
model (two-way random effect model or error component model) with first differences, sometimes known as a Prais-Winston transformation or a Cochrane-Orcutt transformation; (2) a dynamic model with lagged dependent variables with two slightly different approaches known as one- or two-step general methods of moments (GMM) estimators as in Arellano and Bond (1991) or Arellano and Bover (1995); (3) a weightadjusted combination of the White and Newey-West estimator to handle both the heteroscedasticity and the autocorrelation in the model; or (4) a feasible generalized least squares procedure (FGLS, or a two-state generalized least squares model) as in Parks (1967) and Kmenta (1971), in which the model assumes an autoregressive error structure of the first order $\mathrm{AR}(1)$, along with contemporaneous correlation among cross sections. Unlike a pooled OLS estimation, the Kmenta-Parks method employed here accounts for heteroscedasticity and serial correlation when present. Our choice of estimation method is not immune to criticisms, such as those found in Beck and Katz (1995). One of the main criticisms of the Kmenta-Parks estimates is the possibility of underestimation of standard errors, consequently resulting in an artificially inflated statistical significance. This is why we decided to use both estimators to validate the robustness of our results. Nevertheless, these two estimators should be considered cautiously taking into account the short time frame of the dataset. This is why we also used the GMM estimator as control method. The question is to know whether we want to use the Differenced-GMM or the System-GMM. Blundell and Bond (1998) explain that when the independent variables have a coefficient close to one, then the dependent variable follows a path close to a random walk. In this situation, the Differenced-GMM (Arellano and Bond 1991 ) is a poor estimator, especially when $\mathrm{T}$ is small. This is why the System-GMM was proposed (Blundell and Bond 1998). Moreover, with a small T, the Differenced-GMM is a very weak estimator for autoregressive models such as the growth models. To circumvent this difficulty, we have defined our "ratio" variable. The System-GMM is derived from the estimation of a system of two simultaneous equations, one in levels (with lagged first differences as instruments) and the other in first differences (with lagged levels as instruments) (Presbitero 2005).

The System-GMM is superior to the Differenced-GMM when series are persistent. There is a significant reduction in the finite sample bias due to the use of additional moment conditions (Blundell, Bond, and Windmeijer 2000). However, in our case, because of our transformation (the "ratio" variable), it is possible that the series are not persistent. Then, there is a chance that the estimates are biased downward. It can also come from a weak instrument. Considering this uncertainty, the use of the System-GMM estimator should be preferred and its estimates should lie between OLS and the OLS with fixed effects.

As a consequence of our finite sample, we will focus more on the consistency of the statistical significance across the different methods and the sign of the coefficients rather than the size of the coefficients. Our aim here is to provide a preliminary set of guidelines to study convergence with this new database more than providing the exact impact in absolute terms.

The second step in our analysis will be to regress by industry by separating them into 10 groups representing the available data. ${ }^{5}$ Thus, we will have used the dataset in two ways and extracted as much information as we could for these three countries. In a couple of years, when the dataset has a longer time frame, the econometric results will be a little more robust.

\footnotetext{
${ }^{5}$ See groups in appendix.
} 


\section{Results}

The results are presented separately for the three countries: Brazil, China and India. We evaluate each of the proposed models (equations 4, 5 and 6). These results allow us to determine whether there has been convergence between these countries and the United States during the last decade in terms of labor productivity for the manufacturing sector. Finally, in a second step, we focus at the industry level to analyze the areas of convergence during this period. Several elements can be identified in light of these estimations.

First, with ordinary least squares, the coefficient is significant for the three countries. However, and as predicted, this method of estimation produces positively biased coefficients, which therefore tend to minimize the convergence phenomenon.

These results are actually very interesting as they highlight unconditional convergence of the labor productivity in the manufacturing sector (by OLS) and as this convergence relies on conditions/variables proper to each industry (introduced in the model by the fixed effect dummies). In other words, the difference in the coefficient size implies that even if there is a convergence phenomenon independently of the context, this convergence will be more important considering specific attributes from the different industries.

It proves that convergence is even more important if factors - for example technology transfer through learning-by-doing - are taken into account. Indeed, technology transfer could be easier in certain types of manufacturing industries than in others.

The associated $\mathrm{R}^{2}$ are not very high. It may be considered as reasonable insofar as the only variable RATIO is not expected to fully explain the variation in growth rate of labor productivity. Standard deviations are reasonable, especially since they are corrected for heteroscedasticity.

Finally, it is possible to remark that the convergence phenomenon seems to be faster in India and Brazil than in China. 
Table 1- Results for Brazil

BRAZIL

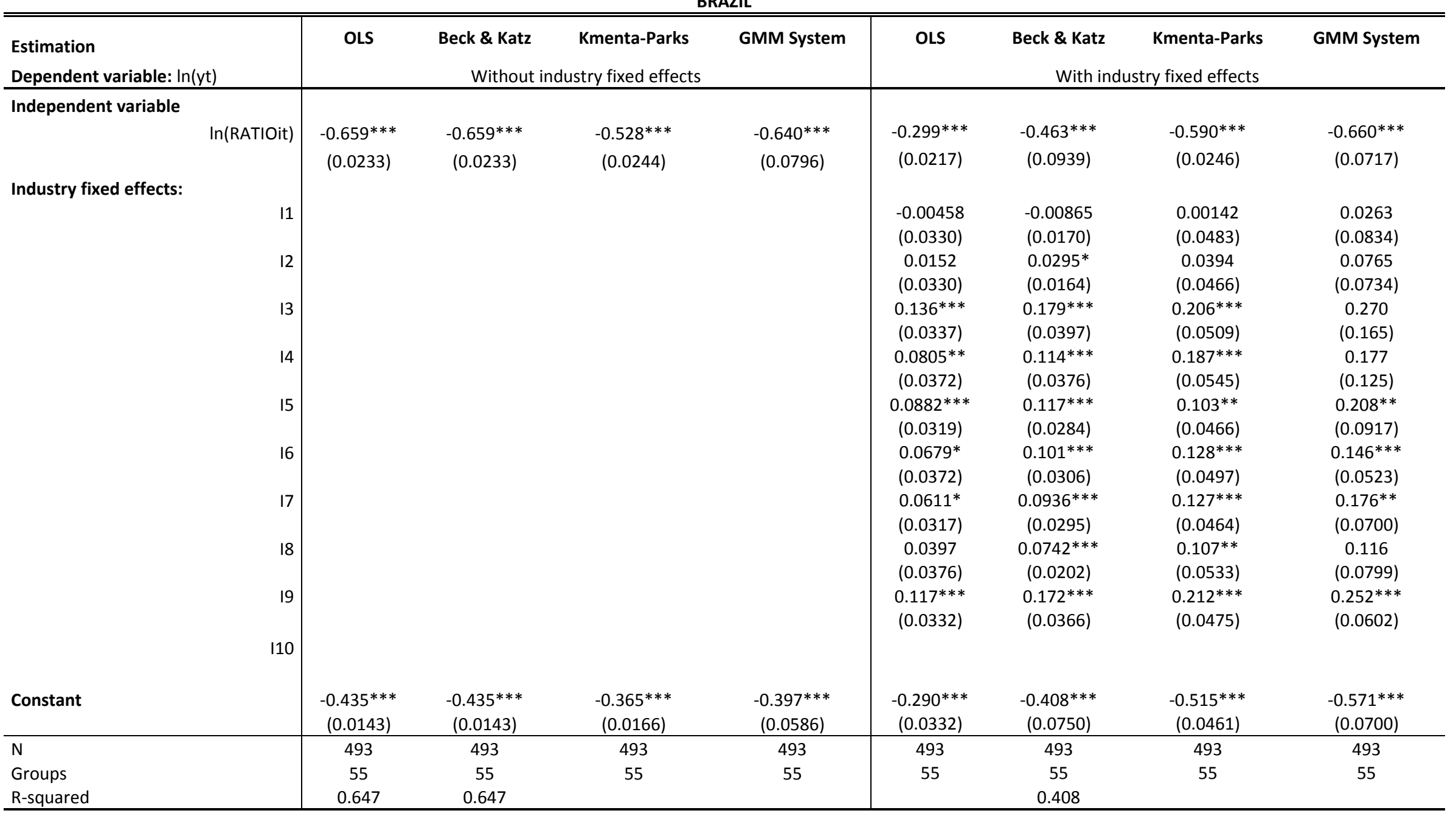

Standard errors in parentheses

*** $p<0.01, * * p<0.05, * p<0.1$ 
Table 2- Results for China

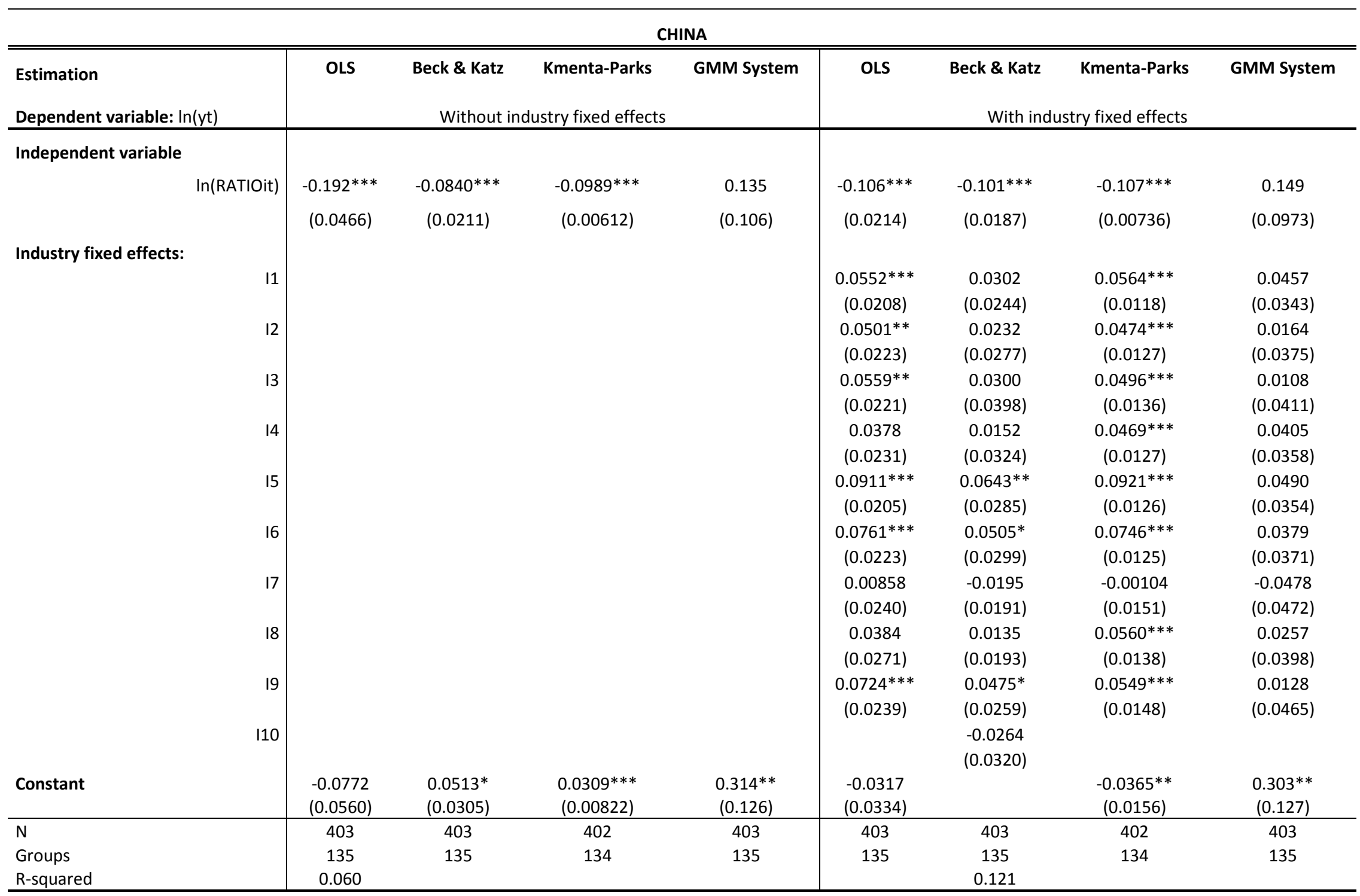

Standard errors in parentheses 
$* * * p<0.01, * * p<0.05, * p<0.1$

Table 3- Results for India

\begin{tabular}{|c|c|c|c|c|c|c|c|c|}
\hline \multicolumn{9}{|c|}{ INDIA } \\
\hline Estimation & OLS & & Kmenta-Parks & GMM System & OLS & Beck \& Katz & Kmenta-Parks & $\begin{array}{c}\text { GMM } \\
\text { System }\end{array}$ \\
\hline Dependent variable: $\ln (\mathrm{yt})$ & \multicolumn{4}{|c|}{ Without industry fixed effects } & \multicolumn{4}{|c|}{ With industry fixed effects } \\
\hline \multicolumn{9}{|l|}{ Independent variable } \\
\hline In(RATIOit) & $-0.864 * * *$ & $-0.232 * * *$ & $-0.282 * * *$ & $-0.689 * * *$ & $-0.183 * * *$ & $-0.303 * * *$ & $-0.375 * * *$ & $-0.764 * * *$ \\
\hline & $(0.0310)$ & $(0.0847)$ & $(0.0185)$ & $(0.101)$ & $(0.0179)$ & $(0.0915)$ & $(0.0204)$ & $(0.0938)$ \\
\hline \multicolumn{9}{|l|}{ Industry fixed effects: } \\
\hline \multirow[t]{2}{*}{11} & & & & & -0.0112 & $-0.137 * * *$ & $-0.0802 * * *$ & $-0.187^{*}$ \\
\hline & & & & & $(0.0237)$ & $(0.0407)$ & $(0.0231)$ & $(0.102)$ \\
\hline \multirow[t]{2}{*}{12} & & & & & 0.0157 & $-0.0755^{* *}$ & -0.00937 & 0.0287 \\
\hline & & & & & $(0.0244)$ & $(0.0305)$ & $(0.0204)$ & $(0.0464)$ \\
\hline \multirow[t]{2}{*}{13} & & & & & 0.0389 & $-0.0574 *$ & -0.0206 & -0.00907 \\
\hline & & & & & $(0.0241)$ & $(0.0304)$ & $(0.0209)$ & $(0.0867)$ \\
\hline \multirow[t]{2}{*}{14} & & & & & 0.0290 & -0.0566 & -0.0161 & 0.0893 \\
\hline & & & & & $(0.0254)$ & $(0.0402)$ & $(0.0208)$ & (0.0939) \\
\hline \multirow[t]{2}{*}{15} & & & & & $0.0612 * * *$ & -0.0218 & 0.0313 & $0.101^{*}$ \\
\hline & & & & & $(0.0223)$ & $(0.0296)$ & $(0.0192)$ & (0.0599) \\
\hline \multirow[t]{2}{*}{16} & & & & & $0.0890 * * *$ & 0.0109 & $0.0703 * * *$ & $0.148^{* *}$ \\
\hline & & & & & $(0.0238)$ & $(0.0285)$ & $(0.0209)$ & $(0.0590)$ \\
\hline \multirow[t]{2}{*}{17} & & & & & $0.0827 * * *$ & 0.00982 & $0.0935 * * *$ & $0.201^{* *}$ \\
\hline & & & & & $(0.0260)$ & $(0.0349)$ & $(0.0235)$ & $(0.0817)$ \\
\hline \multirow[t]{2}{*}{18} & & & & & $0.0746 * *$ & & $0.0688 * * *$ & 0.0973 \\
\hline & & & & & $(0.0296)$ & & $(0.0226)$ & $(0.0607)$ \\
\hline \multirow[t]{2}{*}{19} & & & & & $0.0861 * * *$ & 0.0108 & $0.0771 * * *$ & $0.167^{* * *}$ \\
\hline & & & & & $(0.0260)$ & $(0.0413)$ & $(0.0227)$ & $(0.0583)$ \\
\hline \multirow[t]{2}{*}{110} & & & & & & $-0.0887^{* *}$ & & \\
\hline & & & & & & $(0.0400)$ & & \\
\hline \multirow[t]{2}{*}{ Constant } & $-1.146 * * *$ & $-0.285^{* *}$ & $-0.352 * * *$ & $-0.914 * * *$ & $-0.263 * * *$ & $-0.336 * * *$ & $-0.493 * * *$ & $-1.058 * * *$ \\
\hline & $(0.0423)$ & $(0.115)$ & $(0.0246)$ & $(0.145)$ & $(0.0309)$ & $(0.122)$ & $(0.0318)$ & (0.132) \\
\hline $\mathrm{N}$ & 1100 & 1100 & 1100 & 1100 & 1100 & 1100 & 1100 & 1100 \\
\hline Groups & 139 & 139 & 139 & 139 & 139 & 139 & 139 & 139 \\
\hline R-squared & 0.447 & 0.116 & & & & 0.167 & & \\
\hline
\end{tabular}

Standard errors in parentheses

*** $p<0.01,{ }^{* *} p<0.05, * p<0.1$ 
Again, the goal of this paper is essentially to lay out a new way of measuring convergence benefitting from the availability of a new database. We can, nevertheless, conclude about convergence of labor productivity between Brazil/China/India and the United States in the manufacturing sector. In other words, the greater the gap between the level of labor productivity between Brazil, China or India and the United States in an industry, the greater the rate of productivity growth in Brazil, China or India. As the distance between the two levels of productivity decreases, the growth rate decreases.

Visually, the following graph represents the logarithm of the growth rate of labor productivity in Brazil, China and India against the logarithm of the distance to the border (the variable RATIO). Industries therefore appear, at most, three times (for three times are evaluated 2003-2005, 2004-2006, and 2005-2007) in the case of China and six times in the case of Brazil and India (1998-2000, 1999-2001, 2000-2002, 20032005, 2004-2006, and 2005-2007). The negative slope of the straight lines serves to illustrate the results of the previous regressions.

\section{Figure 6- Growth rate of labor productivity (in log format) in function of the ratio of the labor productivity distance between Brazil and the U.S.}

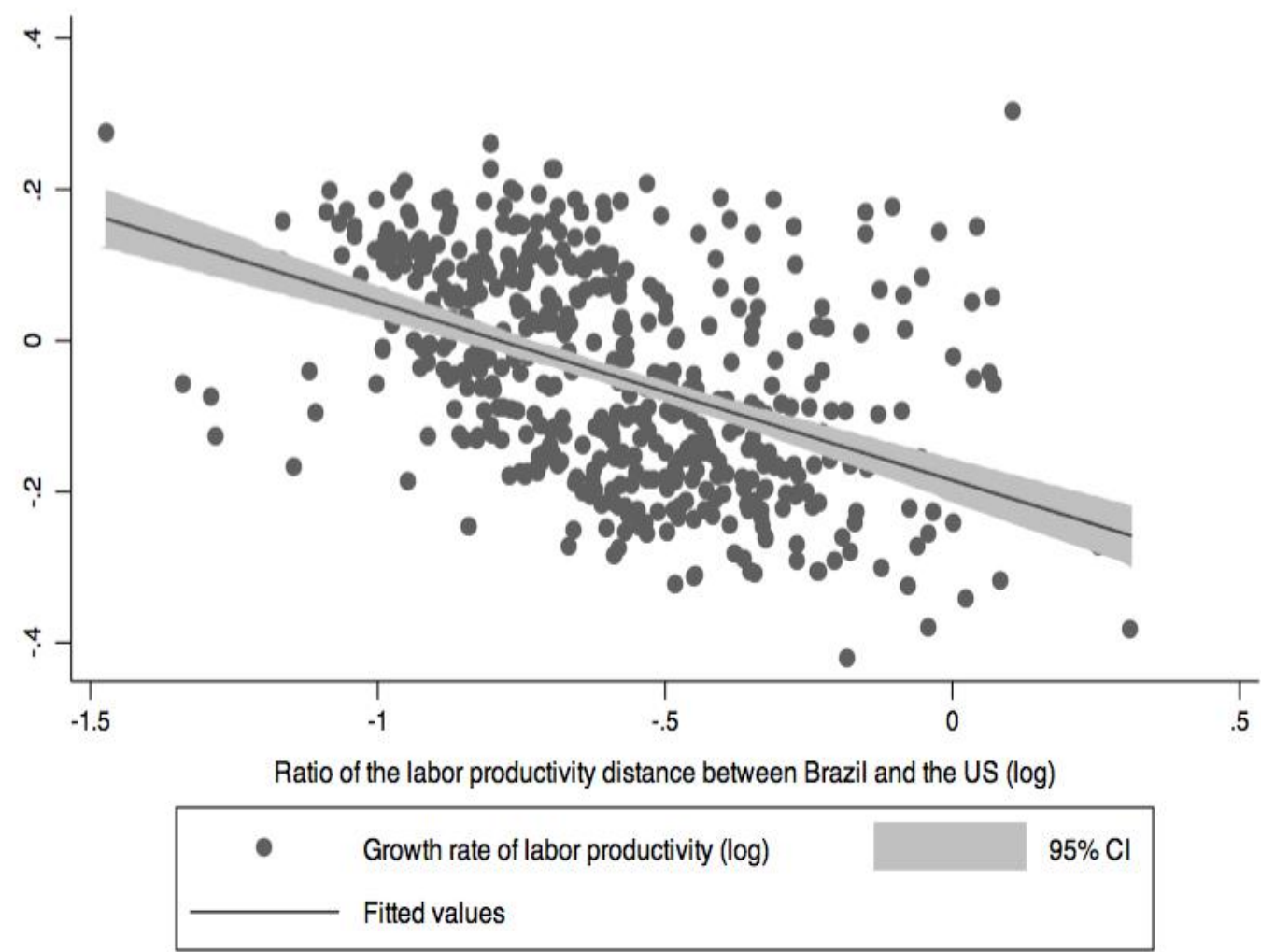


Figure 7- Growth rate of labor productivity (in log format) in function of the ratio of the labor productivity distance between China and the U.S.

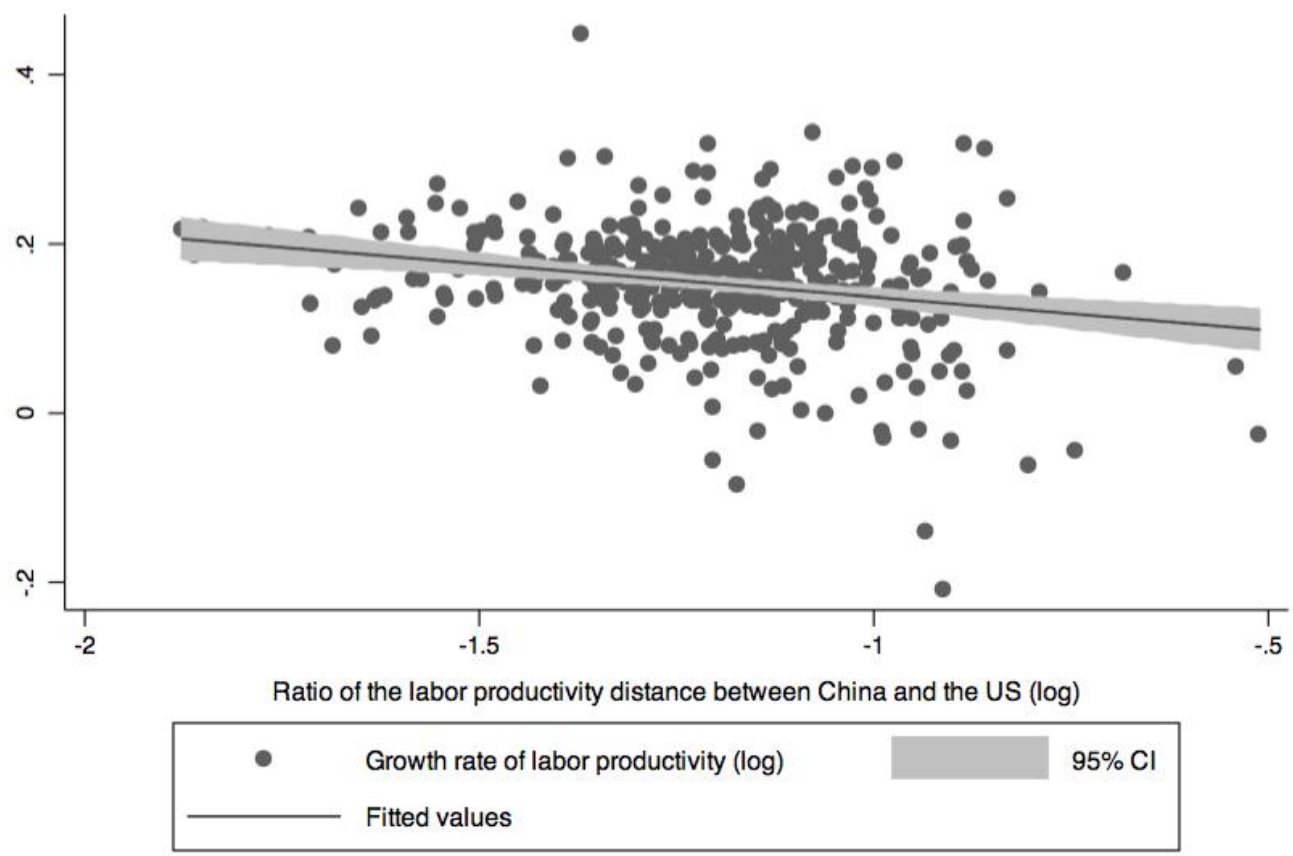

Figure 8- Growth rate of labor productivity (in $\log$ format) in function of the ratio of the labor productivity distance between India and the U.S.

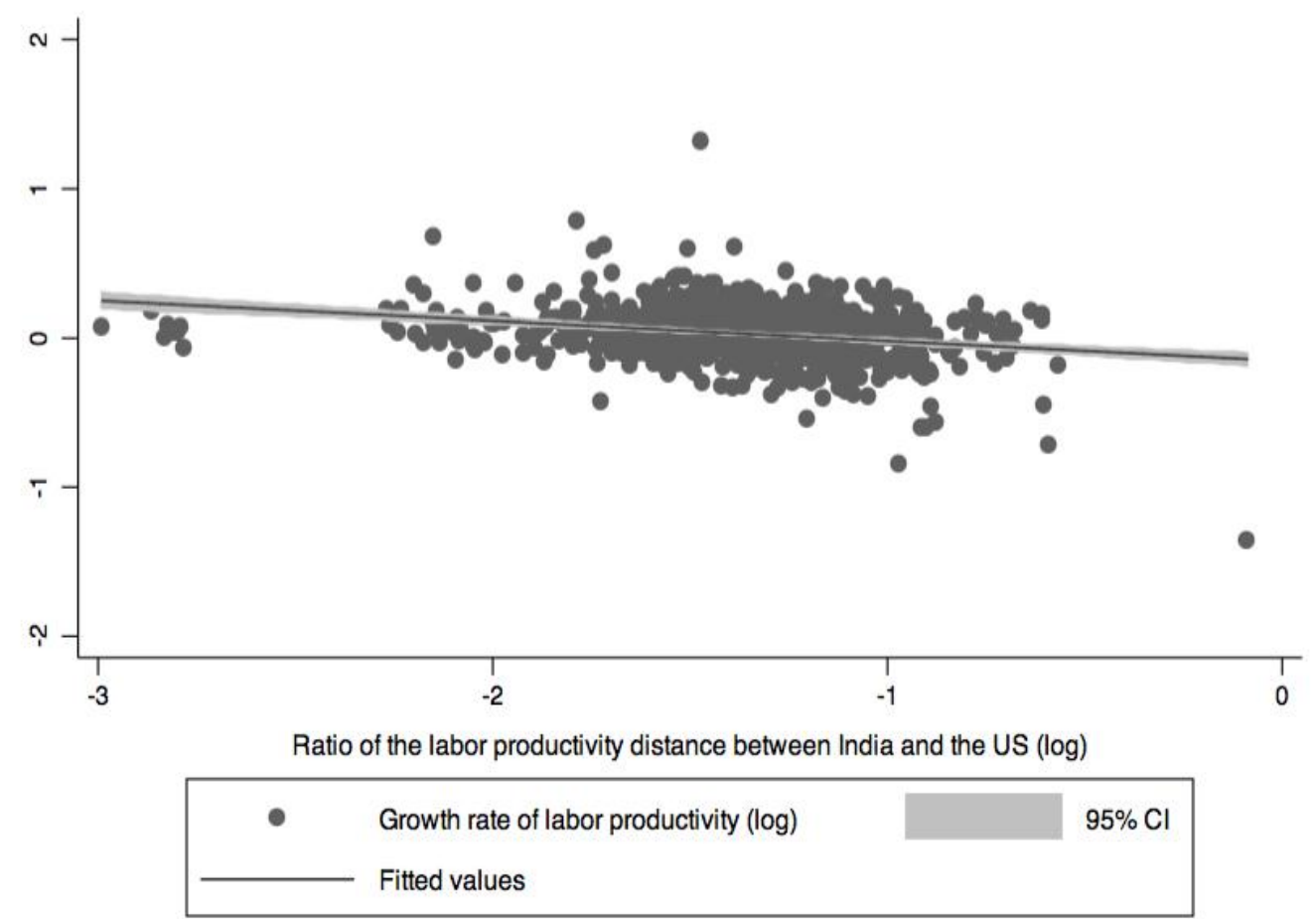


What connection can be made between the convergence of labor productivity and the recent emergence of these countries? As already stated in the introduction, it is important to remember that the manufacturing sector accounts for respectively $60 \%, 93 \%$ and $64 \%$ of Brazilian, Chinese and Indian exports in 2010 (World Bank, 2010). These three economies have been largely open to international trade during the last decade, particularly with their entry in the World Trade Organization (1995 for Brazil and India, and 2001 for China). The general intuition, often used in the literature is: the opening of the economy generates higher revenues and faster growth if the sectors stimulated generate technological changes and gains through "learning-by-doing" (Alwyn Young 1991). ${ }^{6}$ In the case of Brazil, China and India, the manufacturing sector, which represents the majority of exports, may be considered the most stimulated. Obviously, some further research should assess this point.

Now, for our second step, we could analyze the dataset at the industry level. The following tables refer to the regression results for different types of manufacturing industries. Although the small temporal dimension of the data limits the interpretation of these results, it nevertheless provides us with an overview of the levels of convergence of the different industries. It is possible to note that almost all industries seem to converge, which is consistent with our previous results. However, the small sample size could also be the cause of this result. For Brazil, except for wood and paper, all industries seem to converge really fast, with heavy machinery, transport, and textiles in head. For China, the areas of medical equipment, wood and paper, and heavy machinery seem to converge faster. In India, we note transport, medical equipment, and textiles.

${ }^{6}$ Other elements, such as returns to scale, ideas diffusion, elimination of research duplication or enforcement of creative destruction, have also been reported by literature as vectors of sustainable growth (Aghion and Howitt 1992; Grossman and Helpman 1990; L A. Rivera-Batiz and Romer 1991; Segerstrom, Anant, and Dinopoulos 1990). 
Table 4- Log-log, Brazil: OLS estimation by industry

BRAZIL

\begin{tabular}{|c|c|c|c|c|c|c|c|c|c|c|}
\hline \multirow{3}{*}{ Dependent variable: $\ln (y t)$} & \multicolumn{9}{|c|}{ BRAZIL } & \multirow[b]{3}{*}{ Others } \\
\hline & & & & & & & & & \multirow[b]{2}{*}{ Transport } & \\
\hline & Consumables & Textiles & $\begin{array}{l}\text { Wood \& } \\
\text { Paper }\end{array}$ & $\begin{array}{c}\text { Chemicals \& } \\
\text { Pharmaceuticals }\end{array}$ & $\begin{array}{l}\text { Metals and } \\
\text { Plastics }\end{array}$ & $\begin{array}{l}\text { Heavy } \\
\text { Machinery }\end{array}$ & $\begin{array}{l}\text { Electrical } \\
\text { Machines }\end{array}$ & $\begin{array}{c}\text { Medical } \\
\text { Equipment }\end{array}$ & & \\
\hline \multirow[t]{2}{*}{ In(RATIOit) } & $-0.299 * * *$ & $-0.417 * * *$ & -0.082 & $-0.331 * * *$ & $-0.227 * * *$ & $-0.690 * * *$ & $-0.352 * * *$ & $-0.398 * * *$ & $-0.474 * * *$ & $-0.584 * * *$ \\
\hline & 0.059 & 0.052 & 0.067 & 0.067 & 0.05 & 0.063 & 0.048 & 0.079 & 0.089 & 0.081 \\
\hline \multirow[t]{2}{*}{ Constant } & $-0.294 * * *$ & $-0.357 * * *$ & -0.054 & $-0.227 * * *$ & $-0.161 * * *$ & $-0.440 * * *$ & $-0.258 * * *$ & $-0.313^{* * *}$ & $-0.251 * * *$ & $-0.513 * * *$ \\
\hline & 0.044 & 0.034 & 0.045 & 0.042 & 0.033 & 0.035 & 0.03 & 0.053 & 0.049 & 0.065 \\
\hline $\mathrm{N}$ & 54 & 54 & 54 & 27 & 81 & 27 & 90 & 25 & 63 & 18 \\
\hline R-squared & 0.37 & 0.5 & 0.04 & 0.32 & 0.17 & 0.74 & 0.33 & 0.53 & 0.44 & 0.73 \\
\hline
\end{tabular}

Standard errors in parentheses

$* * * p<0.01, * * p<0.05, * p<0.1$

Table 5- Log-log, China: OLS estimation by industry

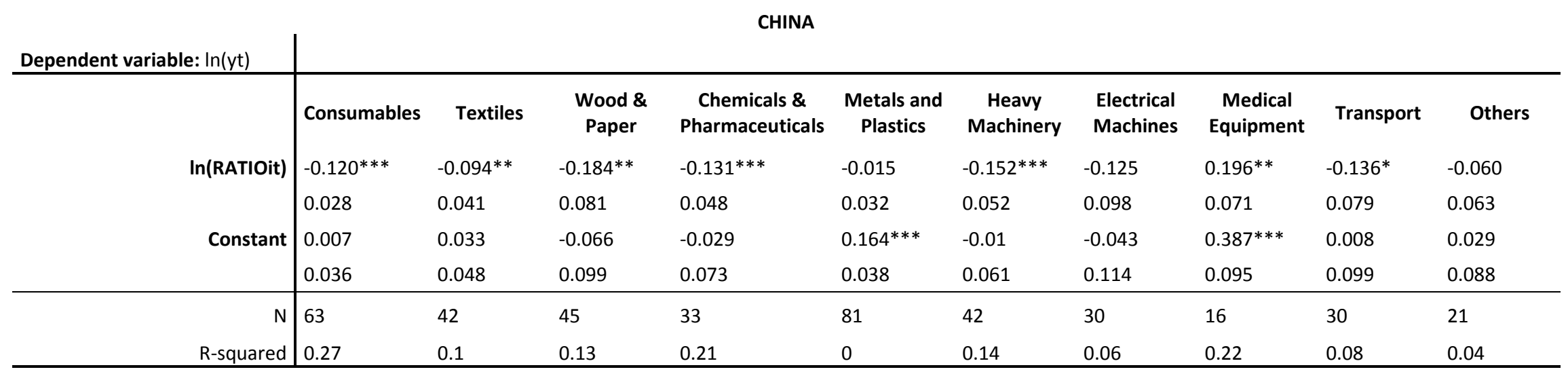

Standard errors in parentheses

*** $p<0.01, * * p<0.05, * p<0.1$ 
Table 6- Log-log, India: OLS estimation by industry

INDIA

\begin{tabular}{|c|c|c|c|c|c|c|c|c|c|c|}
\hline \multirow{2}{*}{\multicolumn{11}{|c|}{ Dependent variable: $\ln (y t)$}} \\
\hline & & & & & & & & & & \\
\hline \multirow{3}{*}{ In(RATIOit) } & Consumables & Textiles & $\begin{array}{l}\text { Wood \& } \\
\text { Paper }\end{array}$ & $\begin{array}{c}\text { Chemicals \& } \\
\text { Pharmaceuticals }\end{array}$ & $\begin{array}{l}\text { Metals and } \\
\text { Plastics }\end{array}$ & $\begin{array}{l}\text { Heavy } \\
\text { Machinery }\end{array}$ & $\begin{array}{l}\text { Electrical } \\
\text { Machines }\end{array}$ & $\begin{array}{l}\text { Medical } \\
\text { Equipment }\end{array}$ & Transport & Others \\
\hline & $-0.11 * * *$ & $-0.307 * * *$ & $-0.161^{*}$ & $-0.095^{* *}$ & -0.071 & $-0.289 * * *$ & -0.094 & $-0.424 * * *$ & $-0.743 * * *$ & $-0.426 * * *$ \\
\hline & 0.032 & 0.068 & 0.088 & 0.038 & 0.046 & 0.083 & 0.059 & 0.152 & 0.174 & 0.115 \\
\hline \multirow[t]{2}{*}{ Constant } & $-0.154 * * *$ & $-0.417 * * *$ & -0.193 & $-0.12 * *$ & -0.054 & $-0.308 * * *$ & -0.074 & $-0.488 * *$ & $-0.872 * * *$ & $-0.583 * * *$ \\
\hline & 0.056 & 0.094 & 0.132 & 0.054 & 0.061 & 0.103 & 0.074 & 0.193 & 0.219 & 0.156 \\
\hline $\mathrm{N}$ & 173 & 112 & 120 & 88 & 216 & 130 & 80 & 46 & 79 & 56 \\
\hline R-squared & 0.07 & 0.17 & 0.05 & 0.08 & 0.01 & 0.14 & 0.02 & 0.19 & 0.41 & 0.31 \\
\hline
\end{tabular}

Standard errors in parentheses

*** $p<0.01, * * p<0.05, * p<0.1$ 


\section{Conclusion}

At a time when the western world is still struggling with the aftermath of the financial crisis, it is interesting to look at the adjustments operated in the emerging countries. In the past, when the western world would slow down, world demand would cause the emerging countries to slow down as well. It is no longer the case. Demand in the new global players can help sustain their own economy, but moreover, the supply chain is productive enough to keep attracting foreign direct investments. This is probably the time of a paradigm shift.

In this context, the purpose of this paper was to highlight the convergence between Brazil/China/India and the U.S. labor productivity in manufacturing over the past 10 years. We tried to make it original in two ways: (1) The study of convergence was done at the industrial sector level and not at a more aggregated level as previous studies. This allowed us to complement these studies by designing a map of which industrial sectors are catching up with the productivity frontier. (2) We also proposed a new approach to convergence. To the extent that this study is original and differs from the classical studies of convergence, we named it $\delta$-convergence. We tested several different models and estimation methods and found that there was indeed $\delta$-convergence: as the distance between the level of labor productivity in Brazil (or China/India) and the United States decreases, the growth rate of labor productivity within the country, in Brazil, China and India decreases. Also, we showed that there are reasons to be convinced by the unconditional convergence explanation. We recognize that the temporal dimension of our study is its main limitation.

While data availability does not allow deeper investigation currently, this work gives a brief overview of what should be further investigated. Indeed, future studies should concentrate at the industry level in order to understand what are the conditions and the mechanisms required to accelerate the convergence phenomenon and, through that, the economic growth. Although study fields of convergence and technology transfer have always been macroeconomic topics, the new globalized world calls for change in our old models and beliefs. 


\section{Bibliography}

Aghion, Philippe, and Peter Howitt. 1992. "A Model of Growth through Creative Destruction." Econometrica 60: 323-51.

Arellano, Manuel, and Stephen Bond. 1991. "Some Tests of Specification for Panel Data: Monte Carlo Evidence and an Application to Employment Equations." The Review of Economic Studies 58 (2): 277-297. doi:10.2307/2297968.

Arellano, Manuel, and Olympia Bover. 1995. "Another Look at the Instrumental Variable Estimation of Error-components Models." Journal of Econometrics 68 (1): 29-51. doi:10.1016/0304-4076(94)01642-D.

Baldwin, Richard, Philippe Martin, and GianmarcoI P. Ottaviano. 2001. "Global Income Divergence, Trade, and Industrialization: The Geography of Growth Take-Offs.” Journal of Economic Growth 6: 5-37. doi:10.1023/a:1009876310544.

Barro, Robert J. 1991. "Economic Growth in a Cross Section of Countries." The Quarterly Journal of Economics 106: 407-43.

- 2012. "Convergence and Modernization Revisited". National Bureau of Economic Research, Inc.

Barro, Robert J., and Xavier Sala-i-Martin. 1992. “Convergence.” Journal of Political Economy 100: 223-51.

AC.

Baumol, William J. 1986. "Productivity Growth, Convergence, and Welfare: What the Longrun Data Show." American Economic Review 76: 1072-85.

Beck, Nathaniel, and Jonathan N. Katz. 1995. "What to Do (and Not to Do) with Time-Series Cross-Section Data." The American Political Science Review 89: 634-647. doi:10.2307/2082979.

Bernard, Andrew B., and Charles I. Jones. 1996. "Comparing Apples to Oranges: Productivity Convergence and Measurement Across Industries and Countries." American Economic Review 86: 1216-38.

Blundell, Richard, and Stephen Bond. 1998. "Initial Conditions and Moment Restrictions in Dynamic Panel Data Models." Journal of Econometrics 87 (1) (November): 115-143. doi:10.1016/S0304-4076(98)00009-8.

Blundell, Richard, Steve Bond, and Frank Windmeijer. 2000. "Estimation in Dynamic Panel Data Models: Improving on the Performance of the Standard GMM Estimator". IFS Working Paper Wo0/12. Institute for Fiscal Studies.

Builter, William H., and Ebrahim Rahbari. 2011. "Global Growth Generators: Moving Beyond Emerging Markets and BRICs”. 55. CEPR Policy Insight.

Carree, M. A., L. Klomp, and A. R. Thurik. 2000. "Productivity Convergence in OECD Manufacturing Industries". Open Access publications from Maastricht University urn:nbn:nl:ui:27-3887. Maastricht University. 
Choi, Hak, and Hongyi Li. 2001. "Economic Development and Growth Convergence in China.” Journal of International Trade E̋ Economic Development 9: 37-54.

Dawson, John, and Amit Sen. 2007. "New Evidence on the Convergence of International Income from a Group of 29 Countries.” Empirical Economics 33: 199-230.

Friedman, Milton. 1992. "Do Old Fallacies Ever Die?" Journal of Economic Literature 30: 2129-32.

Grossman, Gene M., and Elhanan Helpman. 1990. "Comparative Advantage and Long-run Growth." American Economic Review 80: 796-815.

Hwang, Jason Jaemin. 2007. "Patterns of Specialization and Economic Growth". Cambridge, Massachusetts: Harvard University.

Islam, Nazrul. 2003. "What Have We Learnt from the Convergence Debate?" Journal of Economic Surveys 17: 309-362.

Jefferson, Gary, Thomas Rawski, and Yifan Zhang. 2008. "Productivity Growth and Convergence Across China's Industrial Economy." Journal of Chinese Economic and Business Studies 6: 121-140.

Kaitila, Ville, Kari E. O. Alho, and Nuutti Nikula. 2007. "Growth Prospects of Emerging Market Economies in Europe - How Fast Will They Catch up with the Old West?" Discussion Paper 1115. The Research Institute of the Finnish Economy.

Kmenta, Jan. 1971. Elements of Econometrics. Macmillan.

Landesmann, Michael, and Robert Stehrer. 2000. "Potential Switchovers in Comparative Advantage: Patterns of Industrial Convergence". Economics working paper 2000-14. Department of Economics, Johannes Kepler University Linz, Austria.

Leamer, Edward E., and James Levinsohn. 1994. "International Trade Theory: The Evidence”. NBER Working Paper 4940. National Bureau of Economic Research, Inc.

Levchenko, Andrei A., and Jing Zhang. 2011. "The Evolution of Comparative Advantage: Measurement and Welfare Implications." National Bureau of Economic Research Working Paper Series 16806.

Mankiw, Gregory, Edmund Phelps, and Paul Romer. 1995. "The Growth of Nations." Brookings Papers on Economic Activity 1995: 275-326.

Mankiw, N. Gregory, David Romer, and David N. Weil. 1992. "A Contribution to the Empirics of Economic Growth." The Quarterly Journal of Economics 107 (2) (May 1): 407-437. doi: $10.2307 / 2118477$.

Martí, Luisa, Rosa Puertas, and J. Ismael Fernández. 2011. "Industrial Productivity and Convergence in Chinese Regions: The Effects of Entering the World Trade Organisation." Journal of Asian Economics 22: 128-141.

Mundell, Robert A. 1957. "International Trade and Factor Mobility." The American Economic Review 47: 321-335.

Ohlin, Bertil Gotthard. 1933. Interregional and International Trade. Harvard University Press. 
Parks, Richard W. 1967. "Efficient Estimation of a System of Regression Equations When Disturbances Are Both Serially and Contemporaneously Correlated." Journal of the American Statistical Association 62 (318): 500-509. doi:10.2307/2283977.

Presbitero, Andrea Filippo. 2005. "The Debt-Growth Nexus: a Dynamic Panel Data Estimation”. Working Paper 243. Universita' Politecnica delle Marche (I), Dipartimento di Scienze Economiche e Sociali.

Pritchett, Lant. 1997. “Divergence, Big Time.” Journal of Economic Perspectives 11: 3-17.

Quah, Danny. 1993. "Empirical Cross-section Dynamics in Economic Growth.” European Economic Review 37: 426-434.

Repetto, A., and J. Ventura. 1997. "The Leontief-Trefler Hypothesis and Factor Price Insensitivity."

Rivera-Batiz, Luis A., and Paul M. Romer. 1991. "Economic Integration and Endogenous Growth.” The Quarterly Journal of Economics 106: 531-555.

Rivera-Batiz, Luis, and Maria-Angels Oliva. 2003. International Trade: Theory, Strategies, and Evidence. Oxford University Press.

Rodrik, Dani. 2012. "Unconditional Convergence in Manufacturing." http://www.hks.harvard.edu/fs/drodrik/Research\%20papers/Unconditional\%2Oconvergence \%20rev\%205.pdf.

Rybczynski, T. M. 1955. "Factor Endowment and Relative Commodity Prices." Economica 22 (November 1): 336-341.

Sala-i-Martin, Xavier. 2006. "The World Distribution of Income: Falling Poverty and ... Convergence Period.” Quarterly Journal of Economics CXXI: 35 1-397.

Samuelson, Paul A. 1948. "International Trade and the Equalisation of Factor Prices." The Economic Journal 58: 163-184.

. 1949. "International Factor-Price Equalisation Once Again." The Economic Journal 59: $181-197$.

Segerstrom, Paul S., T. C. A. Anant, and Elias Dinopoulos. 1990. "A Schumpeterian Model of the Product Life Cycle." American Economic Review 80: 1077-91.

Shingal, Anirudh. 2010. "Services Growth and Convergence: Getting India's States Together". MPRA Paper 32813. University Library of Munich, Germany.

Solow, Robert M. 1956. "A Contribution to the Theory of Economic Growth." The Quarterly Journal of Economics 70: 65-94. doi:10.2307/1884513.

Somasekharan, Jayasekhar, Syam Prasad, and V. P. Nirmal Roy. 2011. "Convergence Hypothesis: Some Dynamics and Explanations of Agricultural Growth Across Indian States." Agricultural Economics Research Review 24.

The World Bank. 2011. "World Development Indicators."

Trefler, Daniel. 1995. "The Case of the Missing Trade and Other Mysteries." American 25 of 29 
Economic Review 85: 1029-46.

UNIDO. 2012. "INDSTAT4 ISIC Rev.3."

Vries, Gaaitzen J. de, Bart Los, and Fulvio Castellacci. 2010. "Sectoral Productivity Trends:Convergence Islands in Oceans of Divergence”. GGDC Research Memorandum GD118. Groningen Growth and Development Centre, University of Groningen.

Wang, Zheng. 2004. "Regional Divergence of Per Capita GDP in China: 1991-99.” Journal of Chinese Economic and Business Studies 2: 39-53.

Young, Alwyn. 1991. "Learning by Doing and the Dynamic Effects of International Trade." The Quarterly Journal of Economics 106: 369-405.

Young, Andrew, Matthew Higgins, and Daniel Levy. 2005. "Sigma-Convergence Versus BetaConvergence: Evidence from U.S. County-Level Data”. Macroeconomics 0505008. EconWPA. 


\section{Appendix}

\section{Industry groups}

\begin{tabular}{|c|c|}
\hline I1= Consumables & $\begin{array}{l}151 \text { Processed meat, fish, fruit, vegetables, fats } \\
1511 \text { Processing/preserving of meat } \\
1512 \text { Processing/preserving of fish } \\
1513 \text { Processing/preserving of fruit and vegetables } \\
1514 \text { Vegetable and animal oils and fats } \\
1520 \text { Dairy products } \\
153 \text { Grain mill products; starches; animal feeds } \\
1531 \text { Grain mill products } \\
1532 \text { Starches and starch products } \\
1533 \text { Prepared animal feeds } \\
154 \text { Other food products } \\
1541 \text { Bakery products } \\
1542 \text { Sugar } \\
1543 \text { Cocoa, chocolate and sugar confectionery } \\
1544 \text { Macaroni, noodles and similar products } \\
1549 \text { Other food products n.e.c. } \\
155 \text { Beverages } \\
1551 \text { Distilling, rectifying and blending of spirits } \\
1552 \text { Wines } \\
1553 \text { Malt liquors and malt } \\
1554 \text { Soft drinks; mineral waters } \\
1600 \text { Tobacco products }\end{array}$ \\
\hline I2 $=$ Textiles & $\begin{array}{l}171 \text { Spinning, weaving and finishing of textiles } \\
1711 \text { Textile fibre preparation; textile weaving } \\
1712 \text { Finishing of textiles } \\
172 \text { Other textiles } \\
1721 \text { Made-up textile articles, except apparel } \\
1722 \text { Carpets and rugs } \\
1723 \text { Cordage, rope, twine and netting } \\
1729 \text { Other textiles n.e.c. } \\
1730 \text { Knitted and crocheted fabrics and articles } \\
1810 \text { Wearing apparel, except fur apparel } \\
1820 \text { Dressing and dyeing of fur; processing of fur } \\
191 \text { Tanning, dressing and processing of leather } \\
1911 \text { Tanning and dressing of leather } \\
1912 \text { Luggage, handbags, etc.; saddlery and harness } \\
1920 \text { Footwear }\end{array}$ \\
\hline I3=Wood and paper & $\begin{array}{l}2010 \text { Sawmilling and planning of wood } \\
202 \text { Products of wood, cork, straw, etc. } \\
2021 \text { Veneer sheets, plywood, particle board, etc. } \\
2022 \text { Builders' carpentry and joinery } \\
2023 \text { Wooden containers } \\
2029 \text { Other wood products; articles of cork/straw } \\
210 \text { Paper and paper products } \\
2101 \text { Pulp, paper and paperboard } \\
2102 \text { Corrugated paper and paperboard } \\
2109 \text { Other articles of paper and paperboard } \\
221 \text { Publishing } \\
2211 \text { Publishing of books and other publications } \\
2212 \text { Publishing of newspapers, journals, etc. } \\
2213 \text { Publishing of recorded media } \\
2219 \text { Other publishing } \\
222 \text { Printing and related service activities }\end{array}$ \\
\hline
\end{tabular}




\begin{tabular}{|c|c|}
\hline & $\begin{array}{l}2221 \text { Printing } \\
2222 \text { Service activities related to printing } \\
2230 \text { Reproduction of recorded media }\end{array}$ \\
\hline $\begin{array}{l}\text { I4: Chemicals and } \\
\text { pharmaceuticals }\end{array}$ & $\begin{array}{l}241 \text { Basic chemicals } \\
2411 \text { Basic chemicals, except fertilizers } \\
2412 \text { Fertilizers and nitrogen compounds } \\
2413 \text { Plastics in primary forms; synthetic rubber } \\
242 \text { Other chemicals } \\
2421 \text { Pesticides and other agro-chemical products } \\
2422 \text { Paints, varnishes, printing ink and mastics } \\
2423 \text { Pharmaceuticals, medicinal chemicals, etc. } \\
2424 \text { Soap, cleaning and cosmetic preparations } \\
2429 \text { Other chemical products n.e.c. } \\
2430 \text { Man-made fibres }\end{array}$ \\
\hline $\begin{array}{l}\text { I5: Metals and } \\
\text { plastics }\end{array}$ & $\begin{array}{l}251 \text { Rubber products } \\
2511 \text { Rubber tires and tubes } \\
2519 \text { Other rubber products } \\
2520 \text { Plastic products } \\
2610 \text { Glass and glass products } \\
269 \text { Non-metallic mineral products n.e.c. } \\
2691 \text { Pottery, china and earthenware } \\
2692 \text { Refractory ceramic products } \\
2693 \text { Structural non-refractory clay; ceramic products } \\
2694 \text { Cement, lime and plaster } \\
2695 \text { Articles of concrete, cement and plaster } \\
2696 \text { Cutting, shaping and finishing of stone } \\
2699 \text { Other non-metallic mineral products n.e.c. } \\
2710 \text { Basic iron and steel } \\
2720 \text { Basic precious and non-ferrous metals } \\
273 \text { Casting of metals } \\
2731 \text { Casting of iron and steel } \\
2732 \text { Casting of non-ferrous metals } \\
281 \text { Structural metal products; tanks; steam generators } \\
2811 \text { Structural metal products } \\
2812 \text { Tanks, reservoirs and containers of metal } \\
2813 \text { Steam generators } \\
289 \text { Other metal products; metal working services } \\
2891 \text { Metal forging/pressing/stamping/roll-forming } \\
2892 \text { Treatment and coating of metals } \\
2893 \text { Cutlery, hand tools and general hardware } \\
2899 \text { Other fabricated metal products n.e.c. }\end{array}$ \\
\hline I6: Heavy machinery & $\begin{array}{l}291 \text { General purpose machinery } \\
2911 \text { Engines and turbines (not for transport equipment) } \\
2912 \text { Pumps, compressors, taps and valves } \\
2913 \text { Bearings, gears, gearing and driving elements } \\
2914 \text { Ovens, furnaces and furnace burners } \\
2915 \text { Lifting and handling equipment } \\
2919 \text { Other general purpose machinery } \\
\text { 292 Special purpose machinery } \\
\text { 2921 Agricultural and forestry machinery } \\
2922 \text { Machine tools } \\
2923 \text { Machinery for metallurgy } \\
\text { 2924 Machinery for mining and construction } \\
\text { 2925 Food/beverage/tobacco processing machinery } \\
\text { 2926 Machinery for textile, apparel and leather } \\
2927 \text { Weapons and ammunition } \\
2929 \text { Other special purpose machinery }\end{array}$ \\
\hline
\end{tabular}




\begin{tabular}{|c|c|}
\hline & 2930 Domestic appliances n.e.c. \\
\hline $\begin{array}{l}\text { I7: Electrical } \\
\text { machines }\end{array}$ & $\begin{array}{l}3000 \text { Office, accounting and computing machinery } \\
3110 \text { Electric motors, generators and transformers } \\
3120 \text { Electricity distribution and control apparatus } \\
3130 \text { Insulated wire and cable } \\
3140 \text { Accumulators, primary cells and batteries } \\
3150 \text { Lighting equipment and electric lamps } \\
3190 \text { Other electrical equipment n.e.c. } \\
3210 \text { Electronic valves, tubes, etc. } \\
3220 \text { TV/radio transmitters; line communications apparatus } \\
3230 \text { TV and radio receivers and associated goods }\end{array}$ \\
\hline $\begin{array}{l}\text { I8: Medical } \\
\text { Equipment }\end{array}$ & $\begin{array}{l}331 \text { Medical, measuring, testing appliances, etc. } \\
3311 \text { Medical, surgical and orthopaedic equipment } \\
3312 \text { Measuring/testing/navigating appliances, etc. } \\
3313 \text { Industrial process control equipment } \\
3320 \text { Optical instruments and photographic equipment } \\
3330 \text { Watches and clocks }\end{array}$ \\
\hline I9: Transports & $\begin{array}{l}3410 \text { Motor vehicles } \\
3420 \text { Automobile bodies, trailers and semi-trailers } \\
3430 \text { Parts/accessories for automobiles } \\
351 \text { Building and repairing of ships and boats } \\
3511 \text { Building and repairing of ships } \\
3512 \text { Building/repairing of pleasure/sporting boats } \\
3520 \text { Railway/tramway locomotives and rolling stock } \\
3530 \text { Aircraft and spacecraft } \\
\text { 359 Transport equipment n.e.c. } \\
\text { 3591 Motorcycles } \\
3592 \text { Bicycles and invalid carriages } \\
3599 \text { Other transport equipment n.e.c. }\end{array}$ \\
\hline I10: Others & $\begin{array}{l}3610 \text { Furniture } \\
369 \text { Manufacturing n.e.c. } \\
3691 \text { Jewelery and related articles } \\
3692 \text { Musical instruments } \\
3693 \text { Sports goods } \\
3694 \text { Games and toys } \\
3699 \text { Other manufacturing n.e.c. } \\
3710 \text { Recycling of metal waste and scrap } \\
3720 \text { Recycling of non-metal waste and scrap }\end{array}$ \\
\hline
\end{tabular}

